\title{
ZeLENÉ STŘECHY: STŘEŠNí SYSTÉM SNIŽUJící NÁKLADY NA VytáPĚNí a CHLAZENí
}

\section{Green Roofs: Roof System Reducing Heating AND CoOling COSTS}

\author{
Konasova Sarka*1, Reis Vagner da Silveira² \\ ${ }^{1}$ Universidade Federal do Rio de Janeiro, Av. Pedro Calmon. 550, Prédio da Reitoria, Rio de Janeiro, \\ Brasil
}

${ }^{2} U F R J$, COPPE, Engenharia Civil - Meio Ambiente, Cidade Universitária, Rio de Janeiro - RJ, 21941-901, Brasil, rsvagner@gmail.com (tel. +55 21 99934-4336)

\begin{abstract}
Abstrakt - CZ
Zelené střechy se řadí mezi pasivní systémy budovy, jež přispívají $\mathrm{k}$ tepelné stabilitě místností pod střechou jak $v$ letním, tak $v$ zimním období. Zelená střecha může často zásadním způsobem přispět $k$ tepelné rovnováze chráněného prostoru. $V$ posledních deseti letech bylo provedeno mnoho studií, jež se zabývaly energetickými př́nosy zelených střech z hlediska energetické náročnosti budov. $Z$ těchto studií vyplývá, že instalací přírodní krytiny je možno dosáhnout sní̌ení energie na zimní vytápění i na letní chlazení. Zelená střecha, jakožto tepelná izolace, snižuje množství energie na provoz budovy a zmírňuje tepelné ztráty.

Tento článek shrnuje současnou literaturu a poukazuje na situace, ve kterých zelené střechy mohou hrát důležitou roli z hlediska úspory energie na vytápění a chlazení díky zlepšené tepelně izolační funkci střechy, vpřípadě extenzivního vegetačního pokryvu i bezvýrazného přetí̌ení střešní konstrukce a tím spojeným naddimenzováním. Je důležité podotknout, že tyto úspory energie vždy závisí na konkrétním klimatu, na typu budovy i dispozici a typu střešní konstrukce.
\end{abstract}

Klíčová slova - CZ

Zelená střecha, náklady, pasivní budova

\section{Abstract - EN}

Green roofs are among the passive building systems that contribute to the thermal stability of the rooms under the roof in both summer and winter. Green roofs can provide a significant contribution to the thermal balance of the protected space. Over the past ten years, many studies have been carried out to investigate the energy benefits of green roofs in terms of the energy performance of buildings. These studies show that the installation of vegetated cover can achieve energy savings for both winter heating and summer cooling. The green roof, as a thermal insulation, reduces the amount of building operating energy costs and reduces heat losses.

This article summarizes current literature and points to situations in which green roofs can play an important role in saving energy for heating and cooling due to improved thermal insulating function of the roof, in case of extensive vegetation coverage without significant overloading of the roof structure and associated over-dimensioning. It is important to note that these energy savings always 
depend on the particular climate, the type of building and the availability and the type of roof structure.

\section{Keywords - EN}

Green roof, costs, energy, passive building system

\section{JEL Classification}

Q51 Valuation of Environmental Effects

DOI: https://doi.org/10.14311/bit.2016.01.06

Editorial information: journal Business \& IT, ISSN 2570-7434, CreativeCommons license @c) (1) published by CTU in Prague, 2016, http://bit.fsv.cvut.cz/

\section{Úvod}

Střecha budovy, jež je zcela nebo částečně pokryta vrstvou vegetace, je známá jako zelená střecha. Zelená střecha je vrstvený systém, skládající se z hydroizolační fólie, rostoucího média a samotné vegetační vrstvy. Zelené střechy mohou často obsahovat další vrstvy, jako např́iklad kořenovou bariérou, odvodnění a zavlažování. V podmínkách České republiky není zavlažovací systém nezbytný, ten se doporučuje zejména $v$ suchém a teplém podnebí.

Zelené střechy nabízí řadu výhod jak pro samotnou budovu, tak i pro její okolní prostředí. Vegetace na střeše produkuje kyslík, zadržuje oxid uhličitý, absorbuje škodliviny ze vzduchu, filtruje částice prachu a zabraňuje jeho viření, zabraňuje přehřivání střech a redukuje výkyvy teplot mezi dnem a nocí, čímž dochází k redukci městských tepelných ostrovů [1]. Funguje jako tepelná a zvuková izolace, zmírňuje kolísání vlhkosti vzduchu a zlepšuje mikroklima [2]. Zpomaluje odtok deštové vody a odlehčuje tak kanalizaci [3], prodlužuje životnost střechy ( $v$ případě dobrého provedení konstrukčních vrstev) [4] a vytváŕí lokální biodiverzitu a místo k odpočinku s možností pěstování květin i zeleniny [5]. Mezi další výhody se řadí snižování spotřeby energie pro vytápění a klimatizaci [6].

Základní rozdělení střech je na extenzivní a intenzivní. Extenzivní vegetační střechy je možné zakládat i na střechách s poměrně malou únosností, kdy tloušt́ka vegetační vrstvy činí 50 až 150 mm. Nízká únosnost podmiňuje rostliny rozšiřující se do plochy, jako jsou trvalky a skalničky, které snesou extrémní podmínky stř́dání tepla, sucha a mrazu. Tento typ střechy je nejméně náročný na údržbu. Na rozdíl od extenzivních střech, intenzivní vegetační střechy (střešní zahrady) je možno zakládat pouze na střechách s větší únosností. Tloušt́ka vegetační vrstvy se pohybuje v rozmezí od 300 do 1000 $\mathrm{mm}$. Na střechách s intenzivním ozeleněním se předpokládá pracovní nebo rekreační pohyb osob. Používají se zpravidla pro rozšíření užitného nebo obytného prostoru [7].

\section{Snížení tepelného toku a albeda střechy}

Zelená střecha přes evapotranspiraci ochlazuje vzduch, a tím dochází ke snížení teploty povrchu střechy a okolí. $V$ horkých letních dnech, může být povrchová teplota zelené střechy chladnější než teplota vzduchu, zatímco povrch konvenční střechy může mít až $50^{\circ} \mathrm{C}[8]$. Exponované oblasti černé střechy můžou v létě dosáhnout až $80^{\circ} \mathrm{C}$, v případě instalace zelené střechy je možné dosáhnout teploty $27^{\circ} \mathrm{C}$ [9]. Jiná studie poukazuje, že za pomocí zelené střechy je možné zredukovat vnitřní teplotu bez použití klimatizace o $3-4^{\circ} \mathrm{C}$ a venkovní teplotu střechy až o $25-30^{\circ} \mathrm{C}$ [10].

Solární odrazivost neboli albedo je specifická schopnost materiálu odrážet infračervené a ultrafialové vinové délky slunečního záření. Gaffin [11] uvádí, že zelené střechy dokážou chladit tak účinně, jak nejjasnější bílá střecha. Albedo zelené střechy je v rozmezí $0,25-0,3$, při zohlednění 
evapotranspirace je udáváno "ekvivalentní albedo" 0,7-0,85 [12], přičemž hodnota odrazivosti standardní černé barvy je 0,05 a standardní bílé je od 0,50 do 0,90 [13].

Lui a Minor [14] zkonstruovali dva různé zelené střešní systémy z lehkého substrátu tlouštky 75 až $100 \mathrm{~mm} v$ kanadském Torontu. Snímače tepelného toku byly umístěny pod membrány zelených střech. Referenční střecha stejného typu bez vegetace byla použita pro srovnání. Měřením zjistili, že tepelný př́růstek skrze zelené střechy byl v létě snížen v průměru o 70 až $90 \%$, a tepelná ztráta byla redukována o 10-30\% v zimě.

\section{Úspora energie}

Práce Nichaou a kol. [15] demonstruje, jak zelená střecha může snížit spotřebu energie v budovách $s$ různým stupněm izolace. Zaznamenali vnitřní teploty dvou budov $v$ Aténách s podobnými izolačními vlastnostmi, kdy jedna z budov měla zelenou střechou. Celý experiment probíhal v průběhu tří dnů v červenci. Bylo zjištěno, že $v$ budově, jejíž střecha byla bez vegetace, vnitřní teplota překročila $30^{\circ} \mathrm{C} v$ $68 \%$ doby. $V$ př́padě budovy se zelenou střechou došlo $\mathrm{k}$ prekekročení $30^{\circ} \mathrm{C}$ pouze $v 15 \%$ doby. Denní průměrná, maximální a minimální teplota se od sebe lišili o 1 až $3^{\circ} \mathrm{C}$. Na tento experiment byl použit simulační program TRNSYS pro výpočet ročních energetických požadavků administrativních budov $v$ Aténách s rozdílnými izolačními hodnotami střešních konstrukcí. Jejich výsledky jsou uvedeny v tabulce 1.

Tab. 1: Potenciální roční úspory energie při instalaci zelené střechy ${ }^{1}$, Nichaou et al. (2001) [15]

\begin{tabular}{|c|c|c|c|c|c|}
\hline $\begin{array}{c}\text { Střešní } \\
\text { konstrukce }\end{array}$ & $\begin{array}{l}\text { Součinitel prostupu } \\
\text { tepla konstrukce U } \\
\text { (W/m2K) bez zelené } \\
\text { střechy }\end{array}$ & $\begin{array}{c}\text { Součinitel prostupu tepla } \\
\text { konstrukce } U \text { (W/m2K) } \\
\text { zelené střechy }\end{array}$ & $\begin{array}{l}\text { Roční úspory } \\
\text { energie \% za } \\
\text { topení }\end{array}$ & $\begin{array}{l}\text { Roční úspory } \\
\text { energie \% za } \\
\text { chlazení }\end{array}$ & $\begin{array}{l}\text { Potenciální roční } \\
\text { úspory energie při } \\
\text { instalaci zelené } \\
\text { střechy }\end{array}$ \\
\hline Dobře izolovaná & $0.26-0.4$ & $0.24-034$ & $8-9 \%$ & $0 \%$ & $2 \%$ \\
\hline Středně izolovaná & $0.74-0.80$ & $0.55-0.59$ & $13 \%$ & $0-4 \%$ & $3-7 \%$ \\
\hline Bez izolace & $7.76-18.18$ & $1.73-1.99$ & $45-46 \%$ & $22-45 \%$ & $31-44 \%$ \\
\hline
\end{tabular}

Wong a kol. [16] prováděli experimenty na střeše $v$ Singapuru pro záznam teploty $v$ různých hloubkách zelených střech s odlišným vegetačním pokryvem. Z výsledků vypočítali tepelný odpor každého typu rostliny. Pro srovnání izolačních účinků různých rostlin užívaných pro zelené střechy byl použit simulační program DOE-2. Na základě modelace izolované a neizolované střešní konstrukce byl stanoven účinek rozličných typů výsadby. Výsledky jsou reprezentovány v grafu 1., který zobrazuje spotřebu energie budov $v$ závislosti na povrchu střechy.

\footnotetext{
${ }^{1}$ Potenciální úspory energie zelený střechy na základě úrovně izolace v Aténách, Řecko
} 


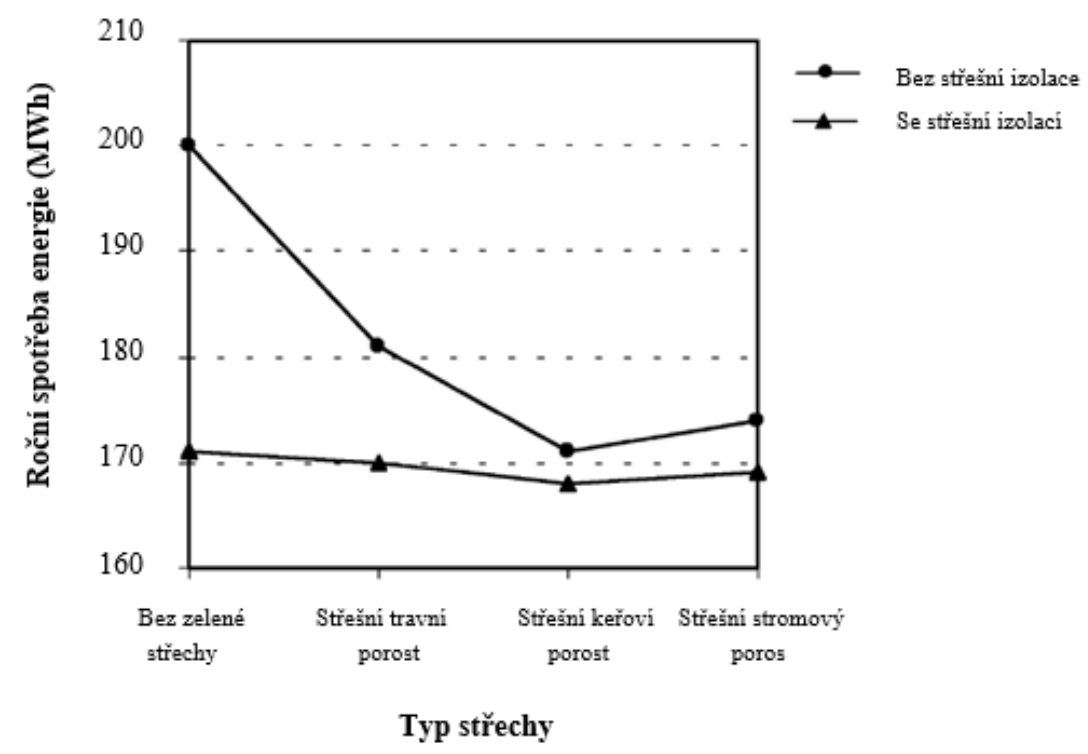

Graf 1: Srovnání roční spotřeby energie dle typu střechy komerční budovy, Wong a kol. [16]

Z grafu je viditelné, že neizolované střešní konstrukce v případě použití travního porostu dosáhnou úspory až $10 \%$ z ročních nákladů na energii ve srovnání s neizolovanou střešní konstrukcí bez vegetačního porostu. Extenzivní zelené střechy jsou díky svému nízkému plošnému zatížením ideální pro rekonstrukce střech se špatnou stávající izolací, jelikož nevyžadují zásahy do konstrukce budovy.

Alcazar a Bass [17] ve své studii došli k závěru, že evapotranspirace a fyziologický proces rostlin mají důležitější roli vúloze tepelné izolace, nežli jen zvýšení tepelného odporu prostřednictvím vegetačního média. Poznatky, jež byly prezentovány $v$ tomto dokumentu, poukazují na fakt, že přítomnost zelené střechy může skutečně výrazně snížit příchozí tepelný tok do střešní konstrukce, a dále do místnosti pod střešní konstrukcí.

Řada prací již analyzovala energetickou náročnost budovy se zelenou střechou za použití modelů sestavených v různých simulačních programech. Výsledky jsou generovány na základě známých nebo naměřených vlastností konstrukce, jako je tepelná vodivost materiálu, a to na zelených i konvenčních střešních konstrukcí. Např́iklad Sailor [18] ve své práci uvádí, že existující matematické modely, které byly vyvinuty pro výpočet přenosu energie prostřednictvím zelených střech, zanedbávají účinky evapotranspirace a časově proměnných půdních tepelných vlastností.

Lazzarin a kol. [19] ve své práci hodnotili pasivní chlazení a roli evapotranspirace při měření na nemocniční budově $v$ severovýchodní Itálii během letní sezóny a to $v$ deštivém a bezdeštném počasí. Experimentální data byla použita $v$ konečném modelu pro výpočet tepelného toku zelenou střechou ve srovnání s podobně izolovanou střechou bez zeleně. Výsledky práce poukazují, že mokré zelené střechy mají více než dvojnásobný chladící efekt prostřednictvím evapotranspirace než zelená střecha v období sucha. Dále bylo zjištěno, že suchá zelená střecha snižuje př́íchozí tepelný tok o $60 \%$ ve srovnání s konvenční střechou bez zeleně.

Zelené střechy mají potenciál ke zlepšení tepelného výkonu střešního systému za pomoci stínění, izolace a evapotranspirace, a tím dosahují snízení energetické poptávky dané budovy. Tohoto potenciálu využil Lee a kol. [20] ve své studii, kde se zaměřili na hodnocení tepelně izolačních vlastností vegetativních střech, aby poukázali na to, že zelené střechy fungují jako izolační vrstva pro budovy. Z jejich studie vyplývá, že zelené střechy mohou ušetřit od $1,8 \mathrm{kWh} / \mathrm{m} 2$ do $6,8 \mathrm{kWh} / \mathrm{m}^{2}$ v prípadě chlazení a $6,44 \mathrm{kWh} / \mathrm{m}^{2}$ ve vytápění. Studie byla provedena v Portland State University (USA) v obdobných klimatických podmínkách, jako se nachází Česká republika. V současné době, v 
roce 2015 , cena $1 \mathrm{kWh}$ je v průměru $4,75 \mathrm{Kčc}^{2}$ na území České republiky. $V$ př́padě $100 \mathrm{~m}^{2}$ zastavěné plochy se zelenou střechou mohou roční úspory na chlazení činit 855 Kč a úspory na vytápění 3 059Kč. Úspory energie se mohou lišit mezi jednotlivými typy zelených střech a $v$ závislosti na klimatických podmínkách.

Široká paleta výhod spojených se zelenými střechami, zejména jejich potenciál snižovat energetické požadavky na vytápění a chlazení, dala podnět $k$ tomu, aby $i$ jeden z nejuznávanějších systémů certifikace udržitelnosti budov LEED [21] podporoval zelenou infrastrukturu. Při instalaci vegetačního souvrství je možné získat až 34 bodů ze 110 potřebných k obdržení nejvyšší Platinové certifikace.

Všechny tyto studie jsou krokem vpřed ke kvantitativnímu posouzení energetických př́nosů zelených střech jak pro laickou, tak zejména pro odbornou veřejnost při zvažování instalace zelené střechy. S ohledem na tuto práci je dále důležité vzít v potaz, že je v České republice možné požádat z dotačního programu Nová zelená úsporám o podporu na instalaci půdorysné plochy vegetačního souvrství zelené střechy. Studie vypracována Karáskem a kol. [22], která vyhodnocuje efektivnost investice do zelených technologii, umožňuje, aby si potencionální investoři mohli zhodnotit ekonomickou návratnost a dopady na životní prostředí v př́ipadě obdržení dotace.

\section{Závěr}

V dnešní době je důležité se opět obrátit na př́rodu, která byla po staletí běžnou součástí života lidí. Je třeba si opět osvojit metody, jak získávat energie z obnovitelných přírodních zdrojů, anebo využit prírodních principů prímo při konstrukci domu, takjak je tomu v př́padě instalace zelených střech. $V$ mnoha př́padech zelené střechy totiž nabízejí především smysluplné využití střešní plochy, která jinak zůstává nevyužita.

Existuje mnoho výhod, jež zelené střechy mohou nabídnout. Jedna z těchto výhod je možnost úspory energie, kdy zelená střecha může snižit roční spotřebu energie na vytápění a chlazení. Bylo provedeno mnoho studií potvrzujících tuto výhodu, jež také posoudily rozsah možných úspor energie zelených střech.

Na stavebnictví je $v$ současnosti vyvíjen tlak směrem $k$ udržitelnosti $v$ souvislosti s evropskou legislativou, která zavadí snižování spotřeby energie, zvyšování podílu obnovitelných zdrojů a redukci emisí skleníkových plynů, proto je důležité vyzdvihnout potenciál zelených střech, jakožto obnovitelného nástroje $\mathrm{k}$ redukci energie, ale také k redukci emisí skleníkových plynů.

\section{Poděkování}

Příspěvek vznikl za podpory Studentské grantové soutěže ČVUT, grantu č. (SGS17/020/OHK1/1T/11).

\section{Literatura}

[1] BANTING, D. (2005): Report on the environmental benefits and costs of green roof technology for the City of Toronto, Ryerson University, Toronto.

[2] YANG, J., YU, Q. \& GONG, P. (2008): Quantifying air pollution removal by green roofs in Chicago, Atmospheric Environment 42 (31) 7266-7273. https://doi.org/10.1016/j.atmosenv.2008.07.003

[3] MENTENS, J., RAES, D. \& HERMY, M. (2006): Green roofs as a tool for solving the rainwater runoff problem in the urbanized 21st century?, Landscape and Urban Planning 77 217-226. https://doi.org/10.1016/j.landurbplan.2005.02.010

\footnotetext{
${ }^{2}$ Energie 123, Aktuální (průměrná) cena $1 \mathrm{kWh}$ elektřiny

http://www.energie123.cz/elektrina/ceny-elektricke-energie/cena-1-kwh/
} 
[4] TEEMUSK, A. \& MANDER, U. (2009): Green roof potential to reduce temperature fluctuations of a roof membrane: a case study from Estonia, Building and Environment 44 (3) 643-650. https://doi.org/10.1016/j.buildenv.2008.05.011

[5] KOEHLER, M. (2003): Plant survival research and biodiversity: lessons from Europe, Greening Rooftops for Sustainable Communities, Chicago, pp. 313-322.

[6] CASTLETONA, H.F., STOVINB, V., BECKC, S.B.M. \& DAVISONB, J.B. (2010): Green roofs; building energy savings and the potential for retrofit, Elsevier, Energy and Buildings, pp.1583-1590.

[7] LIAPOR, Extenzivní a intenzivní ozelenění střech,[online]: http://www.liapor.cz/cz/extenzivni-intenzivniozeleneni-strech

[8] LIU, K. \& BASKARAN, B. (2003): Thermal Performance of Green Roofs Through Field Evaluation (PDF), National Research Council of Canada, Report No. NRCC-46412.

[9] PECK, S. W. \& CALLAGHAN, C. (1999): Greenbacks from green roofs: Forging a new industry in Canada. Canada Mortgage and Housing Corporation. Ottawa: CMHC.

[10] FiBRE - Findings in Built and Rural Environments (2007): Can Greenery Make Commercial Buildings More Green? Cambridge University.

[11] GAFFIN, S. R. (2005): Energy balance modelling applied to a comparison of white and green roof cooling efficiency, Greening Rooftops for Sustainable Communities, Washington, DC.

[12] GARRISON, N. \& HOROWITZ, C. (2012): Looking Up: How Green Roofs and Cool Roofs Can Reduce Energy Use, Address Climate Change, and Protect Water Resources in Southern California, RDC Report.

[13] FEMP - Federal Energy Management Program (2004): Green Roofs, U.S. Department of Energy, Energy Efficiency and Renewable Energy, the National Renewable Energy Laboratory.

[14] LUI, K. \& MINOR, J. (2005): Performance evaluation of an extensive green roof, Greening Rooftops for Sustainable Communities, Washington, DC.

[15] NIACHOU, A. (2001): Analysis of the green roof thermal properties and investigation of its energy performance, Energy and Buildings 33 (7), 719-729. https://doi.org/10.1016/S0378-7788(01)00062-7

[16] WONG, N.H. (2003): The effects of rooftop garden on energy consumption of a commercial building in Singapore, Energy and Buildings 35 (4), 353-364. https://doi.org/10.1016/S0378-7788(02)00108-1

[17] ALCAZAR, S. \& BASS, B. (2005): Energy performance of green roofs in amulti storey residential building in Madrid, Greening Rooftops for Sustainable Communities, Washington, DC.

[18] SAILOR, D.J. (2008): A green roof model for building energy simulation programs, Energy and Buildings 40 (8), 1466-1478. https://doi.org/10.1016/j.enbuild.2008.02.001

[19] LAZZARIN, R.M., CASTELLOTTI, F. \& BUSATO, F. (2005): Experimental measurements and numerical modelling of a green roof, Energy and Buildings 37 (12), 1260-1267. https://doi.org/10.1016/j.enbuild.2005.02.001

[20] LEE, A., SAILOR, D., LARSON, T. \& OGLE, R. (2007): Developing a web-based tool for assessing green roofs, Greening Rooftops for Sustainable Communities, Minneapolis, Green Roofs for Healthy Cities.

[21] DOBIÁŠ, J. \& MACEK, D. (2014) Leadership in Energy and Environmental Design (LEED) and its Impact on Building Operational Expenditures, Proceedings of the Creative Construction Conference 2014. Budapest: Diamond Congress Kft., 2014, ISBN 978-963-269-434-4.

[22] KARÁSEK, J. \& PAVLICA, J. (2016) Green Investment Scheme: Experience and results in the Czech Republic, Energy Policy. 2016, 90(90), 121-130. ISSN 0301-4215. https://doi.org/10.1016/j.enpol.2015.12.020 